\title{
The Impact of the COVID-19 Lockdown on Urban Street Litter in South Africa
}

\author{
Peter G. Ryan ${ }^{1}$ (D) Kyle Maclean $^{1}$ (D) Eleanor A. Weideman ${ }^{1}$ (D) \\ Received: 17 July 2020 / Accepted: 2 October 2020 / Published online: 6 October 2020 \\ (C) Springer Nature Switzerland AG 2020
}

Abstract The lockdowns instigated to slow the spread of the COVID-19 pandemic offered a unique opportunity to assess how restrictions on human activity affect street litter. We recorded daily litter arrival rates for 50 days in two South African cities from the time of strictest lockdown through two successive easings in regulations. The strict lockdown had no marked impact on litter composition, which was dominated by convenience foods and beverages ( $29 \%$ by number, $34 \%$ by mass) and tobacco products ( $33 \%$ by number, $3 \%$ by mass). The ban on the sale of tobacco products during the lockdown did not greatly reduce the number of cigarette butts and associated packaging. Vehicle parts accounted for $<1 \%$ of litter items ( $2 \%$ by mass) whereas household waste spilled from bins prior to or during collection accounted for $3 \%$ of litter items (14\% by mass). Street litter loads decreased roughly by a factor of three during the strict lockdown. The increase in litter was gradual, suggesting a reduction in compliance with regulations as the lockdown continued. Our results show a clear link between human activity levels and littering.

\section{Highlights}

- Street litter loads increased three-fold in two cities as Covid lockdowns eased.

- Cigarette butts made up 33\% of litter by number despite a ban on tobacco sales.

- There is a clear link between human activity levels and littering.

Keywords Coronavirus pandemic · Litter reduction · Plastic pollution · Urban waste management

Electronic supplementary material The online version of this article (https://doi.org/10.1007/s40710-02000472-1) contains supplementary material, which is available to authorized users.

Peter G. Ryan

pryan31@gmail.com

Kyle Maclean

macleankyle1@gmail.com

Eleanor A. Weideman

el.weideman@gmail.com

1 FitzPatrick Institute of African Ornithology, DSI-NRF Centre of Excellence, University of

Cape Town, Rondebosch 7701, South Africa 


\section{Introduction}

The CoviD-19 pandemic saw an unprecedented global 'lockdown', with almost two-thirds of the world's human population placed under some sort of confinement by early April 2020 (Bates et al. 2020). This offered a unique opportunity to study the impact of humans on the environment (Lindsey et al. 2020; Manenti et al. 2020; Rutz et al. 2020). One of the most immediate and visible impacts was the increase in air quality linked to reduced air pollution (Dutheil et al. 2020; Muhammad et al. 2020; Stratoulias and Nuthammachot 2020, but see Wang et al. 2020). However, little has been reported on the impact of the so-called 'anthropause' (Rutz et al. 2020) on other forms of pollution (Zambrano-Monserrate et al. 2020). It has been suggested that lockdown restrictions prohibiting beach access resulted in cleaner beaches, but that solid waste management challenges were exacerbated by reducing recycling and re-use initiatives, and that additional waste resulted from discarded personal protective equipment such as gloves and face masks (Fadare and Okoffo 2020; Prata et al. 2020; Zambrano-Monserrate et al. 2020). It also has been reported that increased reliance on home delivery of food and groceries during national lockdowns and home quarantines increased the generation of plastic packaging (Scaraboto et al. 2020; Vanapalli et al. 2020). However, empirical support for these claims is limited and we therefore report how a strict lockdown in South Africa affected street litter in two urban centres.

Street litter mainly results from inappropriate disposal of waste by pedestrians and vehicle passengers, although some items fall off vehicles accidentally, for example unsecured loads or pieces of the vehicles themselves, and there may be leakage from poorly designed/managed waste receptacles (Schultz et al. 2013). There are numerous studies of why people litter, with both intrinsic and extrinsic factors affecting the propensity to litter (e.g., Williams et al. 1997; Torgler et al. 2012; Ojedokun 2013; Moqbel et al. 2020). However, surprisingly little appears to have been reported on how litter loads correlate with human activity. On Tasmanian beaches, litter loads are explained in part by the number of people living in the vicinity (Willis et al. 2017), but this result could be confounded by other differences among sites. In the coastal city of Mar del Plata, Argentina, litter loads were higher in areas with more pedestrians and parked cars, although litter loads did not peak in the main tourism season when there is an influx of people to the area, suggesting that other factors such as the frequency of street cleaning may also influence litter loads in the city (Seco Pon and Becherucci 2012).

Given the scarcity of research on how litter loads correlate with human activity, we conducted street surveys in two major South African urban centres during the CovID-19 pandemic. A strict lockdown was implemented in South Africa for five weeks from 27 March 2020, confining all people not involved in essential services to their homes. The gradual easing of restrictions over the following months provided a unique opportunity to assess how litter loads changed as human movement increased. Despite many years of education and awareness campaigns, street litter remains a significant source of mismanaged solid waste, particularly in developing countries (Moqbel et al. 2020), and is a major contributor to aquatic pollution in South Africa (Verster and Bouwman 2020; Weideman et al. 2020a). By improving our understanding of how litter loads vary in response to human activity, we can inform mitigation measures aimed at stopping the release of litter into the natural environment. We hypothesise that litter loads should be lowest during the period of strictest lockdown, and increase as lockdown restrictions eased. 


\section{Study Area and Methods}

In response to the COVID-19 pandemic, the South African government implemented a national lockdown on 27 March 2020, with only people involved in a limited set of essential services allowed to leave home other than to buy food or seek medical attention. This strict 'level 5' lockdown remained in place throughout April 2020. From 1 May, the lockdown was eased to 'level 4', which allowed people to exercise within $5 \mathrm{~km}$ of home for three hours from 6 h00-9 h00. From 1 June, restrictions were eased further to lockdown 'level 3', which saw much greater freedom of movement during the day. Most businesses reopened, and traffic volumes increased close to pre-lockdown levels.

We were issued a permit to conduct street litter surveys from 20 April 2020 in suburbs of Cape Town (Muizenberg) and Durban (Kloof). The two sites are shown in Supplementary Material (SM) Figs SM1 and SM2, respectively. The study areas were selected to include a similar mix of residential and retail areas, and both contained government offices (police station and magistrate's court in Muizenberg; community clinic in Kloof) as well as food shops that remained open during the lockdown. The Cape Town residential area included three areas where household waste is collected weekly. There were no similar collection points in the Durban study area. Litter bins are provided along Main Road in the Cape Town site (two bins within the 190-m long stretch sampled); there were no bins in the Durban study area.

To ensure all litter was removed and that subsequent collections only sampled newly arrived litter, we conducted an initial clean of $400 \mathrm{~m}$ of street margins in Cape Town on the afternoon of 22 April and a $400 \mathrm{~m}$ stretch in Durban on the morning of 24 April. After the initial cleaning, litter was collected from each $400 \mathrm{~m}$ study area every day thereafter for 50 days (Cape Town: 22 April - 10 June, Durban: 24 April - 12 June). In Cape Town, accumulated litter was assigned to the day of collection because litter was collected in the afternoon, whereas Durban litter was attributed to the day before because cleaning took place early each morning. This resulted in 8-9 days of litter accumulation data for level 5 lockdown, 31 days for level 4 lockdown and 9-10 days for level 3 lockdown.

We collected all anthropogenic litter items $>1 \mathrm{~cm}$, but we did not collect organic waste (e.g., fruit peel). We then cleaned, dried and weighed all litter items. We weighed most items to the nearest $0.1 \mathrm{~g}$ on a top pan balance $(0.01 \mathrm{~g}$ for small items), but items $>120 \mathrm{~g}$ were weighed with a spring balance to the nearest $5 \mathrm{~g}(120-500 \mathrm{~g})$ or $50 \mathrm{~g}(>500 \mathrm{~g})$. Litter was categorised according to its material (plastic, glass, wood, paper, metal, etc.) and source: street litter which had evidently been dropped by pedestrians or people in vehicles, and vehiclerelated litter (i.e., loose vehicle parts). In Cape Town, litter found close to bins that had evidently been dropped by rubbish collectors or people rummaging through bins was categorised as bin litter. This category was not relevant to Durban as there were no bins situated within the study area. For both sites, we further categorised street litter according to its use: food packaging such as chip packets or sweet wrappers, hygiene-related items such as face masks, gloves, wet wipes, tissues and toilet paper, and tobacco-related litter such as cigarette butts, matches and lighters.

We used Wilcoxon rank sum tests to compare the number of items and mass of litter found at the two sites. To assess if there was a change in the proportion of plastic litter during the three stages of lockdown, we used chi-square tests. We used Generalised Linear Models (GLMs) to assess how the number and mass of litter items collected per day changed as lockdown levels eased from level 5 to level 3. We modelled the number and mass of items per day as a function of both lockdown level and study day (day 1-50) in the R statistical 
environment (R Core Team 2020), with daily rainfall as a covariate because rain might reduce litter loads by decreasing the number of pedestrians and washing away some litter items. Models were fit for each site separately using a quasi-Poisson distribution to account for the data being overdispersed. Data are reported as means $\pm \mathrm{SD}$ or as median and inter-quartile ranges where data were strongly right-skewed.

\section{Results}

In Cape Town, 3741 litter items (18.7 \pm 9.6 items $100 \mathrm{~m}^{-1} \cdot$ day $\left.^{-1}\right)$ weighing $18.2 \mathrm{~kg}$ $\left(91.0 \pm 146.4 \mathrm{~g} \cdot 100 \mathrm{~m}^{-1} \cdot \mathrm{day}^{-1}\right)$ were collected over the 50 -day survey period, significantly more than the 2271 items $\left(11.4 \pm 4.4\right.$ items $\cdot 100 \mathrm{~m}^{-1} \cdot$ day $\left.^{-1}\right)$ weighing $7.6 \mathrm{~kg}$ $\left(37.9 \pm 40.4 \mathrm{~g} \cdot 100 \mathrm{~m} \cdot \mathrm{day}^{-1}\right)$ collected in Durban (Wilcoxon rank sum tests; number of items: $\mathrm{W}=1932, p<0.001$; mass of items: $\mathrm{W}=1655, p<0.05)$. The GLMs showed that rainfall did not significantly influence litter loads at either site (SM Tables SM1SM4). Furthermore, the GLMs showed that the number of litter items increased at approximately $4 \%$ per day in Cape Town and 2\% per day in Durban as the lockdown progressed (Fig. 1a and b, Table 1, and SM Table SM1) while the mass of litter increased by approximately $13 \%$ per day in Cape Town and $6 \%$ per day in Durban (Fig. 1c and d, and SM Table SM3). At both sites, the GLMs showed that the number of litter items was approximately three times higher in level 3 than during the hard lockdown (Table 1, SM Fig. SM3A, SM Table SM2), while the mass of litter was nine and four times higher in level 3 than level 5 in Cape Town and Durban, respectively (Table 1, SM Fig. SM3B, SM Table SM4).

At both sites, over $95 \%$ of litter items ( $>75 \%$ by mass) appeared to have been deliberately littered by pedestrians or vehicle passengers (Table 2). Of these street litter items, on-the-go food packaging and tobacco-related products accounted for more than $60 \%$ at both sites, although these items contributed less by mass (Table 2). In Cape Town, 5\% of litter items (18\% by mass) came from spillage of domestic refuse put out for municipal rubbish collection on Mondays (Table 2). Despite the ongoing ban on the purchasing of tobacco products, the abundance of tobacco-related products littering the streets increased at both sites throughout the lockdown (SM Fig. SM4) although the proportion of tobacco-related products decreased in Cape Town as the country transitioned from the hard lockdown to levels 4 and 3 (Table 2). Hygiene-related items comprised a relatively small proportion of litter at both study sites (Table 2), with face masks and gloves comprising less than $1 \%$ of litter items overall (1\% by mass). However, the proportion of hygiene-related items did increase slightly as the lockdown progressed (Table 2), particularly in Durban where large numbers of cotton wool and wet wipes were found surrounding the community clinic.

Plastic and card/paper were the most common types of material at both sites in all levels of lockdown, although the higher density of metal resulted in metal making up a larger proportion of litter by mass (Table 3). The proportion of plastic litter by number decreased significantly in both Cape Town $\left(\chi^{2}=26.23\right.$, d.f. $\left.=2, p<0.001\right)$ and Durban $\left(\chi^{2}=4.92\right.$, d.f. $\left.=2, p<0.05\right)$ as the country transitioned to less strict restrictions (Table 3). When measured by mass, the proportion of plastic in Durban was almost two times higher in level 5 than level 3 while in Cape Town, three rubber bicycle tires were found during level 4 of the lockdown, resulting in the proportion of plastic by mass being lower in level 4 than during level 5 (Table 3). 
a) Cape Town - number of items

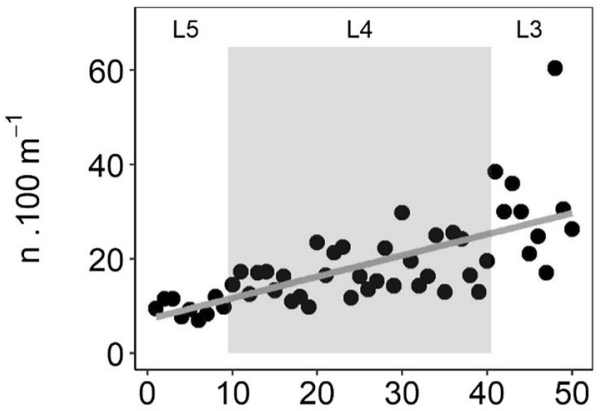

Day of survey

c) Cape Town - mass of items

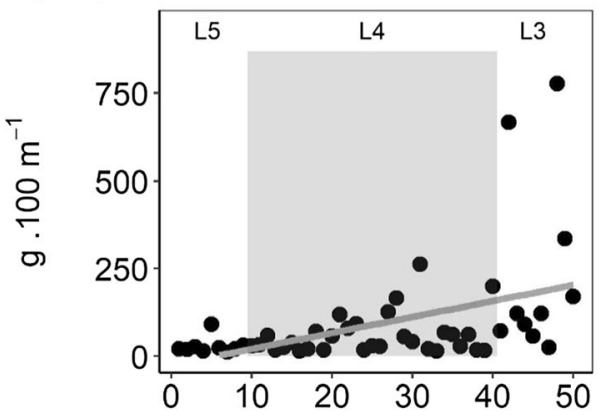

Day of survey b) Durban - number of items

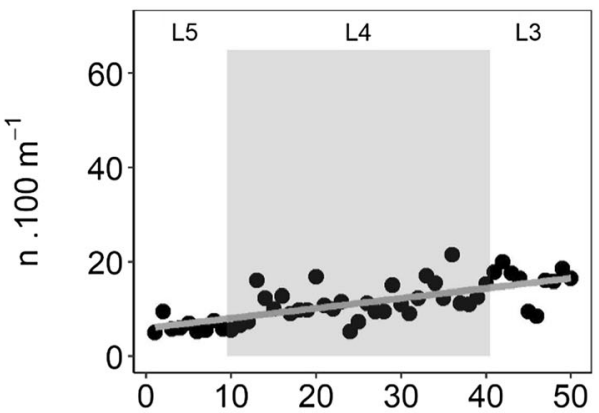

Day of survey

d) Durban - mass of items

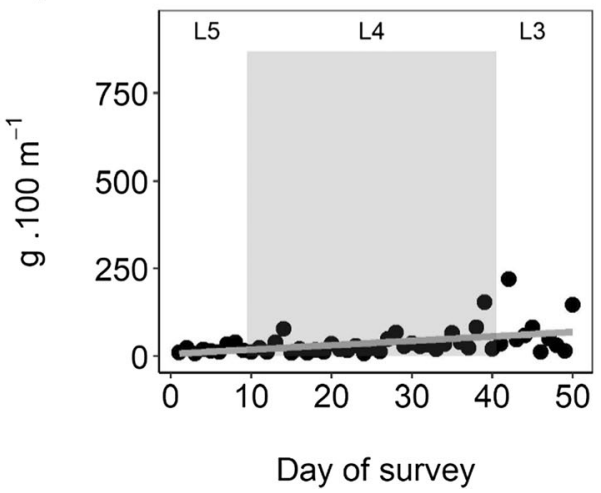

Fig. 1 The (a, b) number and (c, d) mass of litter items collected daily in (a, c) Cape Town and (b, d) Durban as South Africa moved from a hard lockdown (L5) to a more relaxed lockdown (L3). Both study sites included some residential areas as well as shops and municipal offices which remained open during all levels of lockdown. The Cape Town residential area included three areas where household waste was collected weekly, but there were no similar collection points in the Durban study area. The grey shading shows level 4 lockdown. Lines show the best-fit regression between the number and mass of items and the survey day

Table 1 The total number and mass of items in each level of lockdown (L5 to L3) in Cape Town and Durban, as well as the mean \pm standard deviation, and median and interquartile range (IQR) of the number $\left(\mathrm{n} \cdot 100 \mathrm{~m}^{-1} \cdot \mathrm{day}^{-1}\right)$ and mass $\left(\mathrm{g} \cdot 100 \mathrm{~m}^{-1} \cdot \mathrm{day}^{-1}\right)$ of items littered daily. Level 5 was the strictest phase of the lockdown which slowly transitioned to level 3 when most businesses re-opened and traffic increased close to pre-lockdown levels. The number of days (n) each site was surveyed in the different lockdown levels are also shown

\begin{tabular}{|c|c|c|c|c|c|c|}
\hline & \multicolumn{3}{|c|}{ Number of items } & \multicolumn{3}{|c|}{ Mass of items (g) } \\
\hline & L5 & L4 & L3 & L5 & L4 & L3 \\
\hline Cape Town (n) & (9) & $(31)$ & (10) & (9) & (31) & (10) \\
\hline Total & 346 & 2137 & 1258 & 1012.8 & 7459.0 & 9735.7 \\
\hline Mean $\pm \mathrm{SD}$ & $9.6 \pm 1.8$ & $17.2 \pm 4.9$ & $31.5 \pm 12.1$ & $28 \pm 24$ & $60 \pm 59$ & $243 \pm 268$ \\
\hline Median (IQR) & $9.5(3.5)$ & $16.2(7.0)$ & $30.0(9.5)$ & $20(6)$ & 38 (49) & $121(218)$ \\
\hline Durban (n) & (8) & $(31)$ & (11) & $(8)$ & $(31)$ & (11) \\
\hline Total & 206 & 1378 & 687 & 618.1 & 4123.4 & 2841.4 \\
\hline Mean & $6.5 \pm 1.5$ & $11.1 \pm 3.7$ & $15.6 \pm 3.5$ & $19 \pm 12$ & $33 \pm 30$ & $65 \pm 64$ \\
\hline Median (IQR) & $5.9(1.7)$ & $11.0(3.1)$ & $16.5(2.1)$ & $16(15)$ & $23(22)$ & $46(44)$ \\
\hline
\end{tabular}


Table 2 Percentage of litter by number and mass in the three levels of lockdown (L5-L3) that originated from three sources: street litter discarded by people, vehicle parts and household waste (Cape Town only). Street litter was subdivided into on-the-go food waste, tobacco- and hygiene-related products and other litter items

\begin{tabular}{|c|c|c|c|c|c|c|c|c|}
\hline & \multicolumn{4}{|c|}{$\%$ Number } & \multicolumn{4}{|c|}{$\%$ Mass } \\
\hline & L5 & L4 & L43 & Total & L5 & L4 & $\mathrm{L} 43$ & Total \\
\hline \multicolumn{9}{|l|}{ Cape Town } \\
\hline Street litter & 97.1 & 98.6 & 87.0 & 94.6 & 60.6 & 96.1 & 68.5 & 79.4 \\
\hline Food & 36.7 & 31.2 & 34.1 & 32.6 & 69.0 & 40.0 & 33.0 & 38.0 \\
\hline Hygiene & 3.9 & 5.3 & 5.9 & 5.3 & 6.5 & 4.0 & 2.1 & 3.2 \\
\hline Tobacco & 41.8 & 34.4 & 26.6 & 32.7 & 9.5 & 3.8 & 1.9 & 3.1 \\
\hline Other & 17.6 & 29.1 & 33.5 & 29.4 & 15.0 & 52.2 & 63.0 & 55.6 \\
\hline Vehicle parts & 2.6 & 0.5 & 0.1 & 0.6 & 37.6 & 1.5 & 0.6 & 3.0 \\
\hline Household waste* & 0.3 & 0.8 & 13.0 & 4.9 & 1.7 & 2.5 & 30.9 & 17.6 \\
\hline \multicolumn{9}{|l|}{ Durban } \\
\hline Street litter & 100.0 & 99.6 & 99.6 & 99.6 & 100.0 & 93.2 & 98.8 & 95.9 \\
\hline Food & 34.0 & 26.9 & 25.6 & 27.1 & 65.1 & 45.4 & 39.6 & 44.8 \\
\hline Hygiene & 6.3 & 9.2 & 10.5 & 9.3 & 2.8 & 3.8 & 2.8 & 3.3 \\
\hline Tobacco & 35.0 & 34.9 & 37.9 & 35.8 & 2.6 & 4.5 & 2.2 & 3.5 \\
\hline Other & 24.8 & 29.1 & 26.0 & 27.8 & 29.5 & 46.2 & 55.4 & 48.3 \\
\hline Vehicle parts & 0.0 & 0.4 & 0.4 & 0.4 & 0.0 & 6.8 & 1.2 & 4.1 \\
\hline
\end{tabular}

*spilled household litter only in Cape Town

\section{Discussion}

During the strictest lockdown, litter loads were roughly three times less than when restrictions eased, thus demonstrating a clear link between human activity levels and littering. This agrees with anecdotal evidence that the volume of waste collected from litter bins in central

Table 3 Proportion by number and mass of different materials found in the three lockdown levels in Cape Town and Durban

\begin{tabular}{|c|c|c|c|c|c|c|c|c|}
\hline & \multicolumn{4}{|c|}{$\%$ Number } & \multicolumn{4}{|c|}{$\%$ Mass } \\
\hline & L5 & L4 & L3 & Total & L5 & L4 & L3 & Total \\
\hline \multicolumn{9}{|l|}{ Cape Town } \\
\hline Plastic & 70.1 & 64.7 & 57.6 & 62.8 & 35.2 & 27.8 & 52.3 & 41.3 \\
\hline Card/paper & 18.3 & 26.5 & 33.4 & 28.0 & 17.1 & 12.2 & 21.1 & 17.2 \\
\hline Cloth & 0.6 & 1.0 & 1.1 & 1.0 & 0.2 & 1.6 & 1.5 & 1.5 \\
\hline Glass & 0.0 & 0.8 & 1.2 & 0.9 & 0.0 & 13.4 & 12.3 & 12.1 \\
\hline Metal & 4.6 & 3.4 & 5.1 & 4.1 & 46.7 & 16.9 & 10.1 & 14.9 \\
\hline Rubber & 1.7 & 0.6 & 0.3 & 0.6 & 0.8 & 27.1 & 0.2 & 11.3 \\
\hline Wood & 4.6 & 2.8 & 1.2 & 2.4 & 0.1 & 0.9 & 2.1 & 1.5 \\
\hline Other & 0.0 & 0.2 & 0.2 & 0.2 & 0.0 & 0.2 & 0.3 & 0.3 \\
\hline \multicolumn{9}{|l|}{ Durban } \\
\hline Plastic & 63.1 & 56.1 & 58.7 & 57.5 & 76.6 & 49.9 & 30.6 & 44.8 \\
\hline Card/paper & 26.7 & 29.8 & 27.1 & 28.7 & 9.4 & 19.2 & 12.4 & 15.8 \\
\hline Cloth & 0.0 & 0.4 & 0.0 & 0.2 & 0.0 & 6.9 & 0.0 & 3.7 \\
\hline Glass & 0.0 & 0.1 & 0.3 & 0.1 & 0.0 & 4.8 & 20.3 & 10.2 \\
\hline Metal & 4.4 & 4.4 & 4.8 & 4.5 & 13.7 & 18.5 & 33.8 & 23.8 \\
\hline Rubber & 0.0 & 0.1 & 0.3 & 0.1 & 0.0 & 0.0 & 0.2 & 0.1 \\
\hline Wood & 4.4 & 4.6 & 4.2 & 4.4 & 0.1 & 0.2 & 0.4 & 0.2 \\
\hline Other & 1.5 & 4.6 & 4.7 & 4.4 & 0.2 & 0.6 & 2.4 & 1.2 \\
\hline
\end{tabular}


Cape Town halved during the initial stages of the lockdown (Jacobs 2020). There was a tendency for litter to increase steadily throughout our study, even during level 4 (Fig. 1), when restrictions on movement were constant. We interpret this result as a gradual reduction in compliance with regulations as the lockdown continued. The effect of the lockdown on litter loads was likely even greater in most residential areas, because we specifically selected study areas where there were government buildings and sampled close to shops that remained open throughout the lockdown. It has been suggested that littering in developed countries has become more prevalent as lockdowns have eased (e.g., Thomson 2020) but this does not seem to be the case in South Africa, where littering was a major challenge even before the Covid crisis. While we unfortunately lack pre-lockdown litter loads from the two study sites, the daily litter amounts recorded at the end of the study were similar to those reported in previous surveys of street litter in Cape Town (13-62 items $100 \mathrm{~m}^{-1} \cdot \mathrm{day}^{-1}$ and 120 $165 \mathrm{~g} \cdot 100 \mathrm{~m}^{-1} \cdot \mathrm{day}^{-1}$; PGR and EAW unpubl. Data from Newlands and Sea Point in 2018). If anything, litter loads appeared to be lower than usual at the end of our study period because many people continued to stay at home.

Most litter collected during the lockdown appeared to have been littered deliberately, while vehicle parts which had evidently fallen from vehicles comprised $<1 \%$ of litter items. However, spilled household waste on the day of refuse collection accounted for almost one third of the mass of all litter in Cape Town once the lockdown eased (Table 2). This resulted largely from informal waste collectors breaking open bags of refuse to search for recyclable materials to sell (Schenck and Blaauw 2011; Yu et al. 2020). This is less of an issue where refuse bags are put out in plastic bins, but at one site in the study area where houses lack road access and do not have large bins, bags are left loose on the pavement. The municipal collection system is geared to load refuse from plastic bins, and loose litter is often spilled, especially if refuse bags are opened. The marked increase in this source of litter as the lockdown eased and the increase in the inter-quartile range of litter loads (Table 2) reflected the increase in waste 'picking' as restrictions on movement were lifted. A related issue of litter escaping from poorly-designed waste bins (Schultz et al. 2013) was not an issue during the study as the litter bins in the Cape Town study area are designed to prevent wind blowing items out of the bins. The main problem comes if bins are emptied too infrequently, resulting in litter overflowing, or being piled next to bins. Lockdown restrictions were such that this was not an issue during the study.

Smokers typically exhibit a much greater propensity to litter cigarette butts than other litter types (e.g., Schultz et al. 2013), and cigarette butts are often one of the most abundant types of litter collected in street (e.g., Seco Pon and Becherucci 2012) and beach (e.g., Araújo and Costa 2019) surveys. In Cape Town, other daily accumulation studies found that cigarette butts comprise 18-50\% of street litter by number of items (PGR, KM and EAW unpubl. data). The proportion we recorded during the lockdown falls well within this range, irrespective of the lockdown level (Table 2), suggesting that the controversial ban on the sale of cigarettes and other tobacco products during the lockdown had little impact on the amount of smokingrelated litter. This is explained by the dramatic increase in the illegal trade of cigarettes during the lockdown which meant most smokers had easy access to tobacco, despite the nationwide ban (Chingono 2020; Flanagan 2020; Jooste 2020). The prevalence of discarded cigarette butts is worrying because they can easily be washed into stormwater systems and eventually into the aquatic environment (Weideman et al. 2020a). Once in the natural environment, cigarette butts can easily leach several toxic chemicals such as nicotine, arsenic and heavy metals which are toxic to many aquatic species (Micevska et al. 2006; Moriwaki et al. 2009; Slaughter et al. 
2011). It is therefore imperative that mitigation measures aiming at reducing the propensity of smokers to litter are implemented. These include educational campaigns, increased taxes, increased production of biodegradable cigarette butts and the installation of more bins (Araújo and Costa 2019).

Plastic waste generation has increased dramatically during the Covid-19 lockdown. Of particular concern is the increased use of single-use hygiene-related plastics such as masks and gloves which have subsequently been found littering beaches, rivers and streets (Prata et al. 2020; Silva et al. 2020; Vanapalli et al. 2020). In our study site, the number of hygiene-related litter items increased at a similar rate as other types of litter as the lockdown progressed (SM Fig. SM4). However, there was only a small increase in the proportion of hygiene-related items and this was mostly driven by wetwipes and cotton wool found around a local clinic at the Durban site. Overall, masks and gloves only comprised a small proportion of litter which is likely attributable to the widespread use of reusable cotton masks instead of single-use surgical ones. It has also been suggested that people in quarantine or those trying to avoid crowded spaces have been ordering more take away foods and were thus also consuming more singleuse plastic food packaging (Prata et al. 2020; Vanapalli et al. 2020). While the amount of food packaging found littering the streets increased as the lockdown progressed, the proportion of this type of litter remained relatively stable in Cape Town and decreased in Durban. The littering of food packaging has always been a problem in South Africa and is often one of the most common types of plastic litter found on South African beaches (Ryan et al. 2014; Chitaka and von Blottnitz 2019; Weideman et al. 2020b), streets (PGR and EAW unpublished data; Ryan 2020) and stormwater outlets (Weideman et al. 2020a). It is therefore not surprising that the proportion of food-related packaging did not increase as the lockdown progressed, as might be the case in other countries where littering is not as prevalent. It is clear that more mitigation measures are urgently needed to prevent littering in South Africa although it is important to note that there is no single solution and each municipality should assess which measures will work best in their jurisdiction (Godfrey 2019).

The finding that litter increases with human activity is hardly surprising. However, our study re-emphasises that people are the primary cause of litter, and that strategies to reduce litter need to focus mainly on changing human behaviour (Williams et al. 1997). We can only hope that the 'anthropause' not only gives us the opportunity to measure the direct impact of human actions on the planet, but also contemplate ways to reduce those impacts.

Acknowledgements We thank Guy Preston (South African Department of Environment, Forestry and Fisheries) and Gregg Oelofse (City of Cape Town) for arranging permits to conduct litter studies during the CovID-19 lockdown. Vonica Perold and Alison and Dean Maclean assisted with litter collections.

Authors' Contributions Peter Ryan conceived and designed the study. Peter Ryan and Kyle Maclean collected the data; Eleanor Weideman led the data analysis. The first draft of the manuscript was written by Peter Ryan and Eleanor Weideman; all authors read and approved the final manuscript.Data AvailabilityThe litter data are available on request from the authors.

\section{Compliance with Ethical Standards}

Conflicts of Interest The authors declare no conflicts of interest.

Ethics Approval No ethical (human or animal) approval was required to conduct the study. 
Consent to Participate Not applicable.

Consent for Publication Not applicable.

Code Availability R code for the GLMs is available on request from the authors.

\section{References}

Araújo MCB, Costa MF (2019) A critical review of the issue of cigarette butt pollution in coastal environments. Environ Res 172:137-149. https://doi.org/10.1016/j.envres.2019.02.005

Bates AE, Primack RB, Moraga P, Duarte CM (2020) COVID-19 pandemic and associated lockdown as a "Global Human Confinement Experiment" to investigate biodiversity conservation. Biol Conserv 248: 108665. https://doi.org/10.1016/j.biocon.2020.108665

Chingono N (2020) South Africa tobacco ban greeted with cigarette smuggling boom. The Guardian. https://www.theguardian.com/global-development/2020/jun/26/south-africa-tobacco-ban-greeted-withcigarette-smuggling-boom. Accessed 28 Sept 2020

Chitaka TY, von Blottnitz H (2019) Accumulation and characteristics of plastic debris along five beaches in Cape Town. Mar Pollut Bull 138:451-457. https://doi.org/10.1016/j.marpolbul.2018.11.065

Dutheil F, Baker JS, Navel V (2020) COVID-19 as a factor influencing air pollution? Environ Pollut 263: 114466. https://doi.org/10.1016/j.envpol.2020.114466

Fadare OO, Okoffo ED (2020) Covid-19 face masks: a potential source of microplastic fibers in the environment. Sci Tot Environ 737:140279. https://doi.org/10.1016/j.scitotenv.2020.140279

Flanagan J (2020) Coronavirus in South Africa: tobacco smugglers benefit from world's strictest lockdown. The Times. https://www.thetimes.co.uk/article/south-africa-tobacco-smugglers-are-biggest-winners-in-world-sstrictest-coronavirus-lockdown-g0gjjbkh3. Accessed 28 Sept 2020

Godfrey L (2019) Waste plastic, the challenge facing developing countries - ban it, change it, collect it? Recycling 4:3. https://doi.org/10.3390/recycling4010003

Jacobs K (2020) Cape CBD litter down by $50 \%$, allowing for effective deep cleaning. Cape Town etc. https://www.capetownetc.com/news/cape-town-litter-reduces-by-over-50-during-lockdown/. Accessed 21 Sept 2021

Jooste R (2020) Dirt tobacco: how the cigarette ban backfired. Business Maverick. https://www.dailymaverick. co.za/article/2020-07-30-dirty-tobacco-how-the-cigarette-ban-backfired/. Accessed 28 Sept 2020

Lindsey P, Allan J, Brehony P, Dickman A, Robson A, Begg C, Bhammar H, Blanken L, Breuer T, Fitzgerald K, Flyman M, Gandiwa P, Giva N, Kaelo D, Nampindo S, Nyambe N, Steiner K, Parker A, Roe D, Thomson P, Trimble M, Caron A, Tyrrell P (2020) Conserving Africa's wildlife and wildlands through the COVID-19 crisis and beyond. Nat Ecol Evol 4:1300-1310. https://doi.org/10.1038/s41559-020-1275-6

Manenti R, Mori E, Di Canio V, Mercurio S, Picone M, Caffi M, Brambilla M, Ficetola GF, Rubolini D (2020) The good, the bad and the ugly of COVID-19 lockdown effects on wildlife conservation: insights from the first European locked down country. Biol Conserv 249:108728. https://doi.org/10.1016/j. biocon.2020.108728

Micevska T, Warne MJS, Pablo F, Patra R (2006) Variation in, and causes of, toxicity of cigarette butts to a Cladoceran and Microtox. Arch Environ 50:205-212. https://doi.org/10.1007/s00244-004-0132-y

Moqbel S, El-tah Z, Haddad A (2020) Anti-littering in developing countries: motivating the people of Jordan. Waste Manag Res 38:726-733. https://doi.org/10.1177/0734242X19900654

Moriwaki H, Kitajima S, Katahira K (2009) Waste on the roadside, 'poi-sute' waste: its distribution and elution potential of pollutants into environment. Waste Manag 29:1192-1197. https://doi.org/10.1016/j. wasman.2008.08.017

Muhammad S, Long X, Salman M (2020) COVID-19 pandemic and environmental pollution: a blessing in disguise? Sci Tot Environ 728:138820. https://doi.org/10.1016/j.scitotenv.2020.138820

Ojedokun O (2013) The role of socio-demographical and psychological factors in taking littering prevention actions. Int J Adv Psych 2:197-206. https://doi.org/10.14355/ijap.2013.0204.03

Prata JC, Silva ALP, Walker TR, Duarte AC, Rocha-Santos T (2020) COVID-19 pandemic repercussions on the use and management of plastics. Environ Sci Technol 54:7760-7765. https://doi.org/10.1021/acs.est.0 c02178

R Core Team (2020) R: A language and environment for statistical computing. R Foundation for Statistical Computing, Vienna. http://www.R-project. org 
Rutz C, Loretto M-C, Bates AE, Davidson SC, Duarte CM, Jetz W, Johnson M, Kato A, Kays R, Mueller TM, Primack RB, Ropert-Coudert Y, Tucker MA, Wikelski M, Cagnacci F (2020) COVID-19 lockdown allows researchers to quantify the effects of human activity on wildlife. Nat Ecol Evol 4:1156-1159. https://oi. org/10.1038/s41559-020-1237-z

Ryan PG (2020) The transport and fate of marine plastics in South Africa and adjacent oceans. S Afr J Sci 116: 7677. https://doi.org/10.17159/sajs.2020/7677

Ryan PG, Lamprecht A, Swanepoel D, Moloney CL (2014) The effect of fine-scale sampling frequency on estimates of beach litter accumulation. Mar Pollut Bull 88:249-254. https://doi.org/10.1016/j. marpolbul.2014.08.036

Scaraboto D, Joubert AM, Gonzalez-Arcos C (2020) Using lots of plastic packaging during the coronavirus crisis? You're not alone. The Conversation 668: 1077-1093. https://theconversation.com/using-lots-ofplastic-packaging-during-the-coronavirus-crisis-youre-not-alone-135553. Accessed 21 Sept 2020

Schenck R, Blaauw PF (2011) The work and lives of street waste pickers in Pretoria: a case study of recycling in South Africa's urban informal economy. Urban Forum 22:411-430. https://doi.org/10.1007/s12132-0119125-X

Schultz P, Bator R, Large L, Bruni CM, Tabanico JJ (2013) Littering in context: personal and environmental predictors of littering behavior. Environ Behav 45:35-59. https://doi.org/10.1177/0013916511412179

Seco Pon JP, Becherucci ME (2012) Spatial and temporal variations of urban litter in Mar del Plata, the major coastal city of Argentina. Waste Manag 32:343-348. https://doi.org/10.1016/j.wasman.2011.10.012

Silva ALP, Prata JC, Walker TR, Campos D, Duarte AC, Soares AMVM, Barcelò D, Rocha-Santos T (2020) Rethinking and optimising plastic waste management under COVID-19 pandemic: policy solutions based on redesign and reproduction of single-use plastics and personal protective equipment. Sci Tot Environ 742: 140565. https://doi.org/10.1016/j.scitotenv.2020.140565

Slaughter E, Gersberg RM, Watanabe K, Rudolph J, Stransky C, Novotny TE (2011) Toxicity of cigarette butts and their chemical components to marine and freshwater fish. Tob Control 20:i25-i29. https://doi. org/10.1136/tc.2010.040170

Stratoulias D, Nuthammachot N (2020) Air quality development during the COVID-19 pandemic over a medium-sized urban area in Thailand. Sci Tot Environ 746:141320. https://oi.org/10.1016/j. scitotenv.2020.141320

Thomson L (2020) Psychologists explain why people are littering more now lockdown is lifting. Metro. https://metro.co.uk/2020/07/01/psychologists-explain-why-people-are-littering-now-lockdown-lifting12918790/. Accessed 21 Sept 2020

Torgler B, García-Valiñas MA, MacIntyre A (2012) Justifiability of littering: an empirical investigation. Environ Val 21:209-231. https://doi.org/10.3197/096327112X13303670567378

Vanapalli KR, Sharma HB, Ranjan VP, Samal B, Bhattacharya J, Dubey BK, Goel S (2020) Challenges and strategies for effective plastic waste management during and post COVID-19 pandemic. Sci Tot Environ 750:141514. https://doi.org/10.1016/j.scitotenv.2020.141514

Verster C, Bouwman H (2020) Land-based sources and pathways of marine plastics in a south African context. S Afr J Sci 116:7700. https://doi.org/10.17159/sajs.2020/7700

Wang P, Chen K, Zhu S, Wang P, Zhang H (2020) Severe air pollution events not avoided by reduced anthropogenic activities during COVID-19 outbreak. Res Conserv Recycl 158:104814. https://doi. org/10.1016/j.resconrec.2020.104814

Weideman EA, Perold V, Arnold G, Ryan PG (2020a) Quantifying changes in litter loads in urban stormwater run-off from Cape Town, South Africa, over the last two decades. Sci Tot Environ 724:138310. https://doi. org/10.1016/j.scitotenv.2020.138310

Weideman EA, Perold V, Omardien A, Smyth LK, Ryan PG (2020b) Quantifying temporal trends in anthropogenic litter in a rocky shore intertidal habitat. Mar Pollut Bull 160:111543. https://doi.org/10.1016/j. marpolbul.2020.111543

Williams E, Curnow R, Streker P (1997) Understanding littering behaviour in Australia: a review of the literature. Beverage Industry Environment Council, Pyrmont

Willis K, Hardesty BD, Kriwoken L, Wilcox C (2017) Differentiating littering, urban runoff and marine transport as sources of marine debris in coastal and estuarine environments. Sci Rep 7:44479. https://doi.org/10.1038 /srep44479

Yu D, Blaauw D, Schenck R (2020) Waste pickers in informal self-employment: over-worked and on the breadline. Develop Sthn Afr:1-26. https://doi.org/10.1080/0376835X.2020.1770578

Zambrano-Monserrate MA, Ruano MA, Sanchez-Alcalde L (2020) Indirect effects of COVID-19 on the environment. Sci Tot Environ 728:138813. https://doi.org/10.1016/j.scitotenv.2020.138813

Publisher's Note Springer Nature remains neutral with regard to jurisdictional claims in published maps and institutional affiliations. 